\title{
Strategi Kebertahanan Serta Keberlangsungan Usaha Batik Katura di Trusmi Kulon, Kecamatan Plered, Kabupaten Cirebon, Jawa Barat
}

\author{
Yori Pusparani \\ Desain Komunikasi Visual, Institute Teknologi dan Bisnis Kalbis \\ Jalan Pulomas Selatan Kav. 22, Jakarta Timur 13210 \\ Email: yori.pusparani@kalbis.ac.id
}

\begin{abstract}
This study aims to examine the survival strategy and sustainability of the Katura batik business in Trusmi Kulon, Cirebon Regency. The increase in similar craft businesses and competition with modern textiles has made Trusmi batik entrepreneurs have to carry out strategies so that their business can survive. The concept of analysis of this study is based on observing the behavior and actions of rational and effective batik entrepreneurs in accordance with the social, political, economic and ecological environment in which they live. This research method uses qualitative research methods by compiling field data in the form of documentation and interviews with resource persons consisting of batik craftsmen. While data on the development of batik business in Trusmi itself was obtained by the literature approach method. The results of the study can be explained that the survival and sustainability of the Katura batik business is determined by internal factors, namely batik entrepreneurial behavior and external factors such as geographical conditions and market opportunities. The behavior of batik Trusmi entrepreneurs, shown by their tenacity, loyalty, hard work, and creativity, is one of the main factors that determine the success of a business. In addition, the survival and sustainability of batik business is determined by the entrepreneurs in carrying out their business strategies.
\end{abstract}

Keywords: defense and business continuity, katura's batik, trusmi

\begin{abstract}
Abstrak: Studi ini bertujuan untuk mengkaji strategi kebertahanan dan keberlangsungan usaha batik Katura di Trusmi Kulon, Kabupaten Cirebon. Peningkatan usaha kerajinan sejenis dan persaingan dengan tekstil modern membuat para pengusaha batik Trusmi harus menjalankan strategi agar usahanya dapat bertahan. Konsep analisis studi ini berdasarkan pengamatan perilaku serta tindakan pengusaha batik yang rasional dan juga efektif sesuai dengan lingkungan sosial, politik, ekonomi, dan ekologi dimana mereka tinggal. Metode penelitian ini menggunakan metode penelitian kualitatif dengan mengkompilasi data lapangan berupa dokumentasi serta wawancara dengan narasumber yang terdiri dari pengrajin batik. Sementara data tentang perkembangan usaha batik di Trusmi sendiri diperoleh dengan metode pendekatan literatur. Adapun hasil dari penelitian dapat dijelaskan bahwa kebertahanan dan keberlangsungan usaha batik Katura ditentukan oleh faktor internal yaitu perilaku pengusaha batik dan faktor eskternal seperti kondisi geografis dan peluang- peluang pasar. Perilaku pengusaha batik Trusmi yang ditunjukkan dengan sikap ulet, loyal, bekerja keras, dan kreatif merupakan salah satu faktor utama yang menentukan keberhasilan usaha. Selain itu, kebertahanan dan keberlangsungan usaha batik ditentukan oleh para pengusaha dalam menjalankan strategi usahanya.
\end{abstract}

Kata kunci: batik katura, kebertahanan dan keberlangsungan usaha, trusmi

\section{PENDAHULUAN}

Salah satu benda pakai yang memiliki nilai seni tinggi dalam seni rupa Indonesia adalah Batik. Batik adalah sebuah karya seni yang telah berkembang selama bertahun-tahun dan akan semakin berkembang di masa yang akan datang karena didukung oleh perkembangan teknologi, estetika dan ekonomi dinamis. Batik merupakan warisan budaya Indonesia yang telah diakui oleh UNESCO (The United Nations)
Educational, Scientific and Cultural Organization) pada tanggal 2 Oktober 2009. Kota Cirebon merupakan salah satu sentra industri batik nasional. Yang mana terdapat banyak pengrajin batik dengan gaya Cirebonan. Sangat mudah menemukan sentra-sentra batik di kota ini. Namun, tempat yang dapat di jadikan rujukan sebagai wisata batik adalah desa Trusmi Kulon dan desa Trusmi Wetan yang berada diKecamatan Plered, Kabupaten Cirebon. Batik dari daerah sering disebut dengan batik Trusmi. 
[1] Penelitian ini dikhususkan untuk membahas strategi kebertahanan dan keberlangsungan batik Katura berada di desa Trusmi, kabupaten Cirebon. Sanggar batik Katura berdiri pada tahun 2007, terletak di daerah Trusmi Kulon kecamatan Plered Cirebon merupakan sebuah wadah untuk belajar membatik. Sanggar batik ini terbentuk dari sebuah toko batik rumahan yang sekaligus merupakan tempat informasi tentang batik khususnya batik Cirebon.

Batik katura telah melalui pasang surut usaha batik khususnya di daerah Trusmi, Cirebon. Sejak tahun 2000 usaha batik di desa Trusmi mengalami perkembangan yang cukup pesat sehingga dalam hal ini semakin banyaknya persaingan dalam industri sejenis yang membuat penurunan volume penjualan pada kedua usaha batik tersebut. Tercatat ada 660 unit usaha batik khas Cirebonan. [3] Di daerah Trusmi, saat ini ada lebih dari 35 toko batik, baik besar maupun kecil, yang menjual batik dengan berbagai merek dagang. Selain itu, banyaknya industri tekstil dari dalam maupun luar negeri yang membuat kain print dengan motif batik memberi dampak yang cukup besar pada kedua usaha batik tersebut. Untuk menghadapi situasi semacam ini, pengusaha batik harus memiliki pola strategi yang tepat untuk menjaga kebertahanan dan keberlangsungan usahanya. Untuk bertahan, perusahaan dituntut untuk melakukan tindakan di tiga bidang. Pertama, perusahaan tersebut harus mencari cara untuk memperbesar permintaan pasar keseluruhan. Kedua, perusahaan tersebut harus melindungi pangsa pasarnya. Ketiga, perusahaan tersebut harus berusaha meningkatkan pangsa pasarnya lebih jauh, walaupun ukuran pasarnya tetap sama. [1] Selain itu, persaingan dapat terjadi dalam segmen mutu dan harga, maka hal ini perusahaan harus dapat menetapkan harganya sesuai dengan nilai yang diberikan dan dipahami pelanggan. Jika harganya ternyata lebih tinggi daripada nilai yang diterima, perusahaan tersebut akan kehilangan kemungkinan untuk memetik laba dan kehilangan pelanggan. [2] Ada dua pola strategi yang diterapkan dalam mempertahankan usaha batik Katura dalam menjalankan usaha batik. Pertama, yaitu strategi yang bertujuan pada pengembangan modal, strategi pemasaran, serta pengelolaan usaha yang bertujuan agar usahanya dapat berkembang. Kedua, strategi yang dijalankan para pengusaha tersebut yang tujuannya agar tetap dapat memperoleh penghasilan untuk memenuhi kebutuhan hidup mereka. Namun demikian, pola strategi yang disebut di atas dalam pengamatan yang dilakukan selama penelitian ternyata diterapkan secara berbeda sesuai dengan konsep dan tujuan kedua usaha batik ini. Tidak dapat dipungkiri bahwa keberhasilan batik Katura dalam mempertahankan usaha mereka hingga saat ini adalah hasil dari penerapan strategi yang tepat untuk masingmasing usahanya.

Berdasarkan uraian permasalahan di atas, maka dirasakan perlu untuk melakukan penelitian tentang Strategi Kebertahanan dan Keberlangsungan Usaha Batik Katura di Trusmi Kulon, Kecamatan Plered, Kabupaten Cirebon, Jawa Barat.

\section{METODE PENELITIAN}

Metode tentang Strategi Kebertahanan dan Keberlangsungan Usaha Batik Katura di Trusmi Kulon, Kecamatan Plered, Kabupaten Cirebon, Jawa Barat adalah sebagai berikut: Observasi penulis dengan mengamati secara langsung Usaha Batik Katura di Trusmi Kulon, Kecamatan Plered, Kabupaten Cirebon, Jawa Barat untuk melihat keadaan yang sebenarnya agar dapat dilihat Strategi Kebertahanan dan Keberlangsungan Usaha Batik Katura sehingga dapat diterima dan dikenal masyarakat luas; Wawancara dilakukan dengan mewawancarai narasumber dari pihak Batik Katura, yaitu Bapak Katura untuk mendapatkan infromasi tentang Batik Katura; dan Studi Pustaka dilakukan dengan mengumpulkan artikel-artikel yang berhubungan dengan srategi marketing dan sebagainya. Studi Pustaka juga dilakukan untuk mengumpulkan artikel-artikel Batik Katura untuk mengetahui hasil-hasil karya Batik Katura

\section{III.HASIL DAN PEMBAHASAN}

\section{A. Strategi Kebertahanan}

Strategi adalah energi yang menumbuhkan kekuatan bersaing perusahaan-perusahaan di era global. Strategi ini dikembangkan dari respons yang kreatif terhadap perubahan-perubahan internal dan atau eksternal perusahaan [4] Meskipun banyak toko ataupun pengrajin sandal yang menghentikan usahanya, namun masih ada beberapa pengrajin sandal yang masih melanjutkan industri sandal tersebut. Pengrajin sandal yang masih bertahan pasti memiliki beberapa strategi bertahan diantaranya adalah: tentang pemasaran, variasi produk, harga jual, dan mutu produk.

Sama halnya dengan Batik Katura, untuk bertahan dan keberlangsungan usahanya, Batik Katura memiliki strategi yang cukup mumpuni untuk tetap bertahan. 
Manajemen strategik sendiri menurut David (2011 p.37) adalah seni dan pengetahuan untuk memformulasikan, mengimplementasikan, dan melakukan evaluasi keputusan lintas fungsi yang memungkinkan organisasi mencapai tujuan. Pendapat ini menekankan bahwa strategi pada dasarnya adalah sebuah cara sistematis yang telah dirancang oleh perusahaan agar mampu mencapai tujuannya. [5]

\section{B. Asal Usul Batik Cirebon}

Cirebon yang terletak di pantai Utara Jawa di perbatasan Jawa Barat dan Jawa Tengah, dahulu merupakan pelabuhan persinggahan yang ramai. Daerah ini banyak disinggahi kapal, baik dari luar negeri maupun kapal-kapal antar pulau Indonesia seperti: Madura, Lasem, Jambi dan lain-lain. Selain itu, Cirebon juga terkenal karena mempunyai kraton Kasepuhan dan kraton Kanoman. Di samping itu Cirebon merupakan salah satu dari Sembilan pusat penyebaran agama islam, serta bertetangga dengan daerah Garut dan Indramayu yang merupakan penghasil batik. Keadaan dan sifat lingkungan semua ini turut mempengaruhi seni budaya daerah Cirebon, termasuk seni batiknya yang dapat dilihat pada ragam hias serta warnanya. Sebagai akibat hubungan dengan kaum pendatang dari berbagai negeri, yang membawa kepercayaan dan seni budaya masing-masing, maka terjadilah suatu pembauran yang saling mempengaruhi. Tidak mengherankan bila dalam kebudayaan atau kesenian Cirebon, terlihat perpaduan antara corak-corak Tiongkok, Arab, Hindu dengan daerah Cirebon sendiri. Sebagai contoh, dapat dikemukakan misalnya binatang khayal Peksi Naga Liman atau Singa Barong.

\section{Strategi Kebertahanan dan Keberlangsungan Batik Katura}

Terletak di daerah Trusmi Kulon kecamatan Plered Cirebon. Sanggar Batik Katura merupakan sebuah wadah untuk belajar membatik, dimana peserta membatik diajarkan cara membuat batik hingga finishing. Sanggar batik ini terbentuk dari sebuah toko batik mungil dan tempat orangorang mencari informasi tentang batik khususnya batik Cirebon. Pemilik Sanggar Batik Katura, dilahirkan di Trusmi pada tanggal 15 Desember 1952. Beliau adalah seorang yang sangat peduli dengan seni dan budaya, khususnya batik. Beliau anak ke 9 dari 10 bersaudara. Beliau anak dari Ranima dan Kasmin, dan berasal dari keluarga pengrajin batik. Semasa kecil semenjak usia 11 tahun, sepulang sekolah beliau selalu membantu bapak dan ibunya membuat batik. Dengan keuletannya, karyanya hingga kini banyak diminati turis asing seperti turis Jepang. Kurang lebih $80 \%$ turis Jepang mengunjungi batik Katura untuk mengenal dan membeli produk hasil dari batik Katura. Jepang memang baik dalam hal memilih batik, mereka rela membayar mahal atau membayar dengan harga tinggi asal kualitas bahan baik dan motif yang sangat detail. Tidak jarang turis Jepang sering mengunjungi batik Katura karena menurut mereka sejauh ini batik Katura memiliki keunggulan yang mereka inginkan. Dalam melestarikan batik, pemilik tidak jarang menemui kendala dalam usahanya seperti perekonomian yang tidak menentu, bahan baku yang naik dan lain sebagainya, ini semua tidak menyurutkan semangat pemilik dalam upaya melestarikan batik. Terbukti dari banyaknya penghargaan yang diraih oleh pemilik seperti penghargaan upakarti dari presiden Susilo Bambang Yudhoyono pada tahun 2009. Dengan latar belakang beliau yang tak terlalu tinggi, beliau selalu belajar dari sekelilingnya, dan dengan keuletan serta berbekal ilmu membatik dari bapak dan ibunya beliau mampu mendapat Honoris Causa dari University of Hawaii sebagai Master Of Art. Usaha pemilik dalam melestarikan batik belum sepenuhnya mendapat dukungan dari pemerintah setempat. Pada tahun 2014 pemilik pernahdiundang ke Jepang untuk mempromosikan batik, namun undangan tersebut tidak dapat dipenuhi oleh pemilik dikarenakan alasan biaya yang kurang memadai. Pemerintah yang sedia kala ingin memberikan bantuan dana tidak dapat memenuhi dengan alasan tidak ada anggaran. Batik Katura memang gencar dalam hal melestarikan batik melalui motif-motif batik seperti Batik Keratonan, motif ini biasanya memiliki warna yang monoton lalu Batik Pesisiran, motif ini memiliki warna yang bervariasi atau dimodifikasi. Dalam hal produksi pemilik batik Katura ikut terjun langsung dalam proses membatik, selain itu dalam pemilihan bahan dengan kualitas baik juga merupakan ciri dari batik Katura sendiri dibalik motif-motif yang sangat detail. Dalam hal originalitas batik Katura memang memegang kata itu dalam mengeluarkan motif Batik, konsep branding yang diangkat pemilik sebagai ide dalam menciptakan karyanya, 
dapat dilihat pada batik saat pemerintahan Jokowi saat ini, menurut pemilik kedua peranan diatas tidak akan ada efeknya jika kepercayaan terhadap konsumen dan kepercayaan konsumen terhadap batik Katura, maka dari itu pemilik semaksimal mungkin mengutamakan hal tersebut. Ide yang diangkat kedalam sebuah kain yang bergeser menjadi motif batik ialah pada saat pemilik mendengar sesuatu kemudian menuangkan pikirannya kedalam sebuah narasi yang akan menjadi motif batik. Saat ini batik Katura sedang menyelesaikan batik termahal yaitu seharga 15 juta untuk tahap pengerjaan selama kurang lebih empat bulan.

\section{SIMPULAN}

Setelah melihat pembahasan tersebut diatas maka dapat disimpulkan bahwa strategi kebertahanan dan keberlangsungan Batik Katura adalah sebagai berikut: 1) Dalam pemasaran Batik Katura tidak hanya menjual "batik" saja, tapi sebuah kisah dan cerita yang dituangkan kedalam kain batik; 2) Originalitas suatu karya dari produksi kain Batik Katura adalah yang selalu dipegang teguh oleh pemilik; 3) Pemilik ikut terjun langsung dalam proses membatik, sehingga batik yang dihasilkan dapat selesai dengan maksimal; 4) Melestarikan batik melalui cerita merupakan strategi kebertahanan dan keberlangsungan dari Batik Katura; 5) Branding yang dilakukan melalui ide motif batik; 6) Melalui sanggar batik yang didirikan oleh Bapak Katura diharapkan menjadi suatu pembeda dari pembatik lainnya serta dapat menjadi pembelajaran untuk pengunjung dalam mengenal batik; dan 7) Kualitas dari Batik Katura tidak perlu diragukan, karena mengingat waktu pengerjaan yang cukup lama serta penggunaan malam yang diracik sedemikian rupa sehingga menghasilkan karya yang lebih baik.

\section{DAFTAR RUJUKAN}

[1] A. Wulandari," in Batik Nusantara: makna filosofis, cara pembuatan dan industri batik, Yogyakarta, Andi, 2011, hlm. 25.

[2] P. Kotler," in Manajemen Pemasaran Edisi 12 jilid 2, Jakarta, Indeks, 2008, hlm. 38.

[3] Dinas Perindustrian dan Perdagangan, Dinas Perindustrian dan Perdagangan Kabupaten Cirebon, Cirebon, 2009.

[4] B. Permana, "STRATEGI KEBERTAHANAN PENGRAJIN INDUSTRI SANDAL DI DESA WEDORO," Swara Bhumi, vol. 3, no. 3, 2015, hlm 117

[5] R. I. Susanto, "ANALISIS STRATEGI PENGEMBANGAN BISNIS PADA PT. PATRINSAKA,” AGORA, vol. 5, no. 1, 2017, hlm. 2,. 